\title{
SUBMARINE ICE CLIFFS ON THE WEST SIDE OF MCMURDO SOUND, ANTARCTICA
}

\author{
By William L. Stockton \\ (Scripps Institution of Oceanography, University of California, La Jolla, California 92093, \\ U.S.A.)
}

\begin{abstract}
Eight submarine ice cliffs have been observed on the west side of McMurdo Sound. Three of these cliffs (Miers Valley, Cape Chocolate, and Strand Moraines) are associated with known ice-cored moraines and are justifiably regarded as underwater exposures of ice cores in the adjacent coast. The ice cliffs at Explorers Cove and near Herbertson Glacier may also be underwater exposures of ice cores which may be present in adjacent moraines. Some of these ice cliffs may represent unusual submarine accretionary sea-ice structures.

RÉSUMÉ. Falaises de glace sous-marine sur la rive Ouest du McMurdo Sound en Antarctique. On a observé huit falaises sous-marine de glace sur la rive Ouest du McMurdo Sound. Trois de ces falaises (Miers Valley, Cape Chocolate et Strand Moraines) sont associées à des moraines à coeur de glace bien connues, et peuvent être considérées comme le déboucher sous marin d'un glacier rocheux de la côte voisine. Les falaises de glace de Explorers Cove et près du Herbertson Glacier peuvent aussi être des débouchers de glaciers rocheux qui peuvent se trouver dans les moraines adjacentes. Certaines de ces falaises de glace peuvent représenter des exemples rares d'accrétions sous-marines de glace de mer.
\end{abstract}

Zusammenfassung. Submarine Eisklippen an der Westseite des McMurdo Sound, Antarktika. An der Westseite des McMurdo Sound wurden acht submarine Eisklippen festgestellt. Drei dieser Klippe (Miers Valley. Cape Chocolate und Strand Moraines) sind mit bekannten Moränen mit Eiskernen verbunden und daher als unter Wasser hervortretende Eiskerne der anschliessenden Küste erklärbar. Die Eisklippen bei Explorers Cove und nahe dem Herbertson Glacier können ebenfalls submarin hervortretende Eiskerne sein, die in benachbarten Moränen stecken. Einige dieser Eisklippe aber dürften ungewöhnliche, submarin zusammengewachsene Meereisstrukturen sein.

\section{INTRODUCTION}

The presence of coastal ice-cored moraines bordering the west side of McMurdo Sound, Antarctica (Fig. 1), has been known since the early explorations of this century (David and Priestley, 1914; Taylor, 1914, 1922; Debenham, 1921). These ice cores extend from the flanks of Koettlitz Glacier to the southern edge of Blue Glacier. Most of the recent work on ice-cored moraines in Antarctica has focused on those in the Dry Valleys. Notable exceptions are Healy (1975) which summarizes current knowledge of the distribution of coastal ice-cored moraines in the McMurdo Sound area, and Oliver and others (1978) describing the submerged ice faces of the ice core at Cape Chocolate.

The purpose of this paper is to describe eight ice cliffs which were observed underwater during the austral summer of 1981-82 on the west side of McMurdo Sound. These observations suggest the presence of ice cores where they have previously been undetected or, alternatively, are unusual submarine ice structures due to permafrost. They may suggest that the coastline of the west sound is unstable.

\section{METHOdS}

Underwater observations were made with the use of SCUBA. Access to the water was 


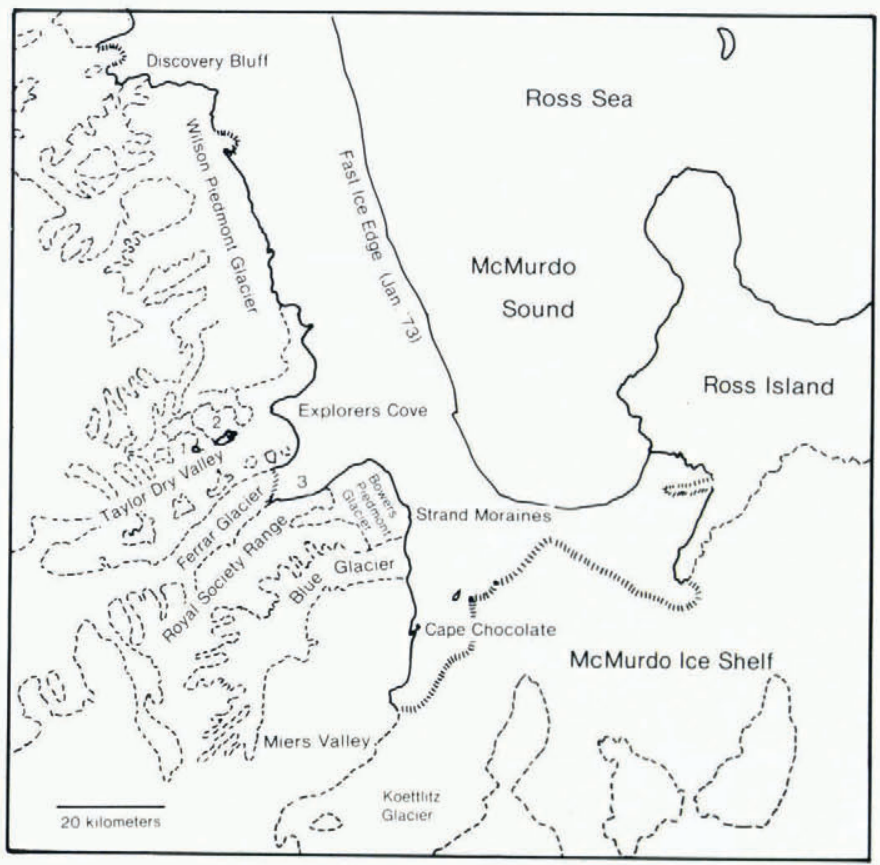

Fig. 1. McMurdo Sound and vicinity (1, Lake Chad; 2, Lake Fryxell; 3, Herbertson Glacier site). The shoreline from the flank of Koettlitz Glacier to Blue Glacier is ice-cored (see text). Map after US Geological Survey: McMurdo Sound, Antarctica $\left(S T 57-60^{*}\left(152^{\circ} \mathrm{E}-180^{\circ} \mathrm{E}\right)\right)$.

obtained through holes blasted through the sea ice or through naturally occurring cracks. The observations reported herein were made from November through early February. Measurements of depth were made with diving depth gauges and should be considered to be accurate to within $0.6 \mathrm{~m}$.

\section{Results}

Underwater ice cliffs were observed at Discovery Bluff, Explorers Cove, near Herbertson Glacier, Strand Moraines, Cape Chocolate, and Miers Valley (Fig. 1). They varied in height from $1 \mathrm{~m}$ to in excess of $60 \mathrm{~m}$. The following is a set of descriptions of these ice cliffs at localities along the western side of McMurdo Sound.

A. Discovery Bluff. The bluff is composed of weakly fractured granite that enters the water almost vertically. At a depth of approximately $5 \mathrm{~m}$ the bluff intersects with the cobble and boulder bottom, which slopes off into deeper water at approximately $30^{\circ}$. The ice cliff at this location (Fig. 2A) is a thin (less than $50 \mathrm{~cm}$ ) veneer of ice which covers the base of the bluff. In areas where the rubble bottom extends into shallower water, the ice covering was not apparent. The overlying sea ice at Discovery Bluff was approximately $2 \mathrm{~m}$ thick. The ice foot, sea ice frozen to the shore, appeared to be frozen to the top of the ice cliff. The upper part of the ice cliff expanded as it merged with the ice foot, creating a $1 \mathrm{~m}$ wide overhang. 


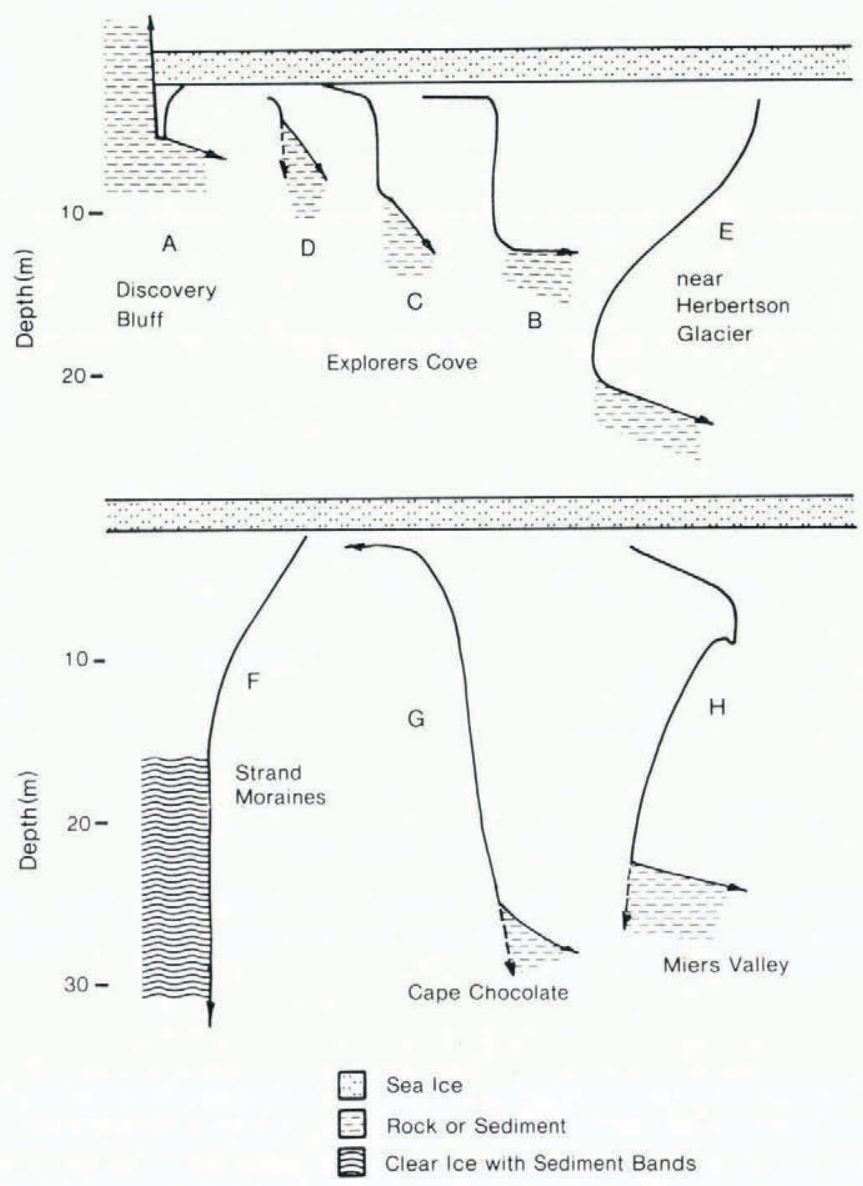

Fig. 2. Aproximate profiles of the submarine ice cliffs.

B-D. Explorers Cove. This cove is at the mouth of Taylor Dry Valley. The shoreline is composed entirely of glacial moraine. The three ice cliffs here share a common morphology but vary in height and lateral extent (Figs 2B-D and 3). The faces were vertical and composed of opaque solid white ice, with no apparent sediment included within the ice. The base of the largest ice cliff (Figs 2B and 3a), which was on the northern side (Fig. 4), was at about $12 \mathrm{~m}$ depth. The top was near the under-surface of the sea ice but not connected to it, the height of the cliff being approximately $9 \mathrm{~m}$. The top of the cliff was flat and at high tide, as the sea ice was lifted upward (approximately $1 \mathrm{~m}$ ), the ice cliff could be seen to extend towards the shore. The width of the top of the ice cliff was not measured due to diving conditions and obscuring crystals of ice; however, it is probably in excess of $10 \mathrm{~m}$. The upper $2-3 \mathrm{~m}$ of the ice cliff was covered with $10 \mathrm{~cm}$ diameter platelets of ice which grew from the surface of the cliff at an angle of $30^{\circ}$ up from horizontal (Fig. 5). The base of the cliff extended outward in a sweeping curve, forming a skirt (Figs 2D and 3a). Neither end of the cliff could be seen underwater; approximately $300 \mathrm{~m}$ of cliff face was seen. To the east, the cliff height decreased to less than $6 \mathrm{~m}$, while to the west it 

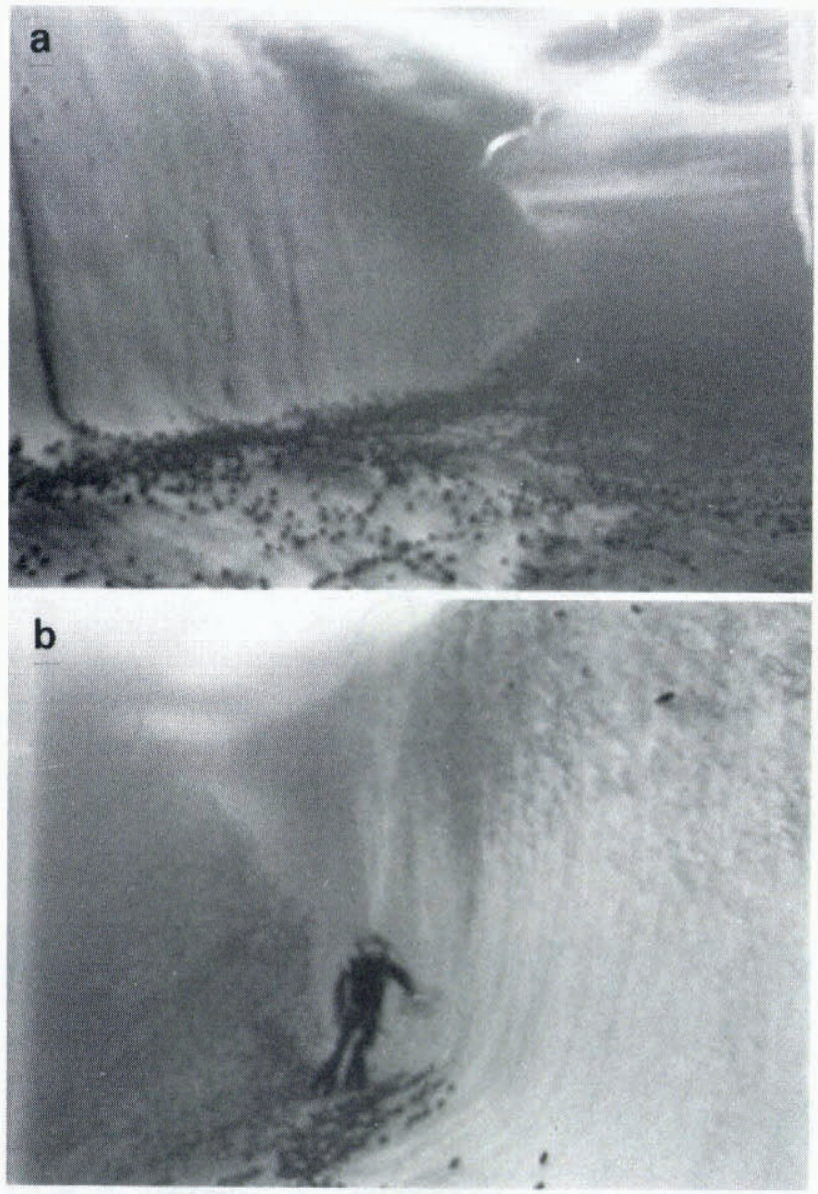

C

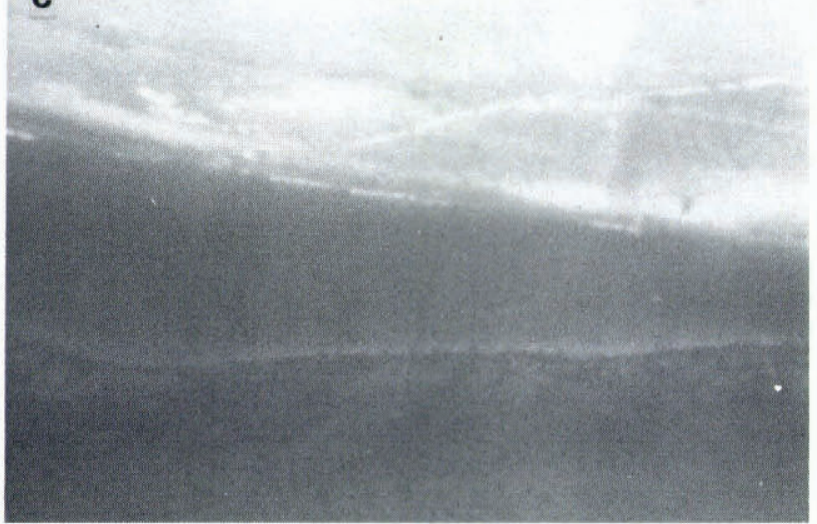

Fig. 3. (a) The ice cliff on the north side of Explorers Cove, designated "B" (see Figs $2 B$ and 4). The height to the left is approximately $9 \mathrm{~m}$. (b) Ice cliff " $\mathrm{C}$ " (see Figs $2 \mathrm{C}$ and 4) on the south side of Explorers Cove. The height to the right is approximately $6 \mathrm{~m}$. Note the rough texture of the upper parts of the cliff. (c) A distant view of ice cliff " $C$ ". The photograph is angled at approximately $20^{\circ}$. The height of the ice cliff to the left is approximately $6 \mathrm{~m}$. 


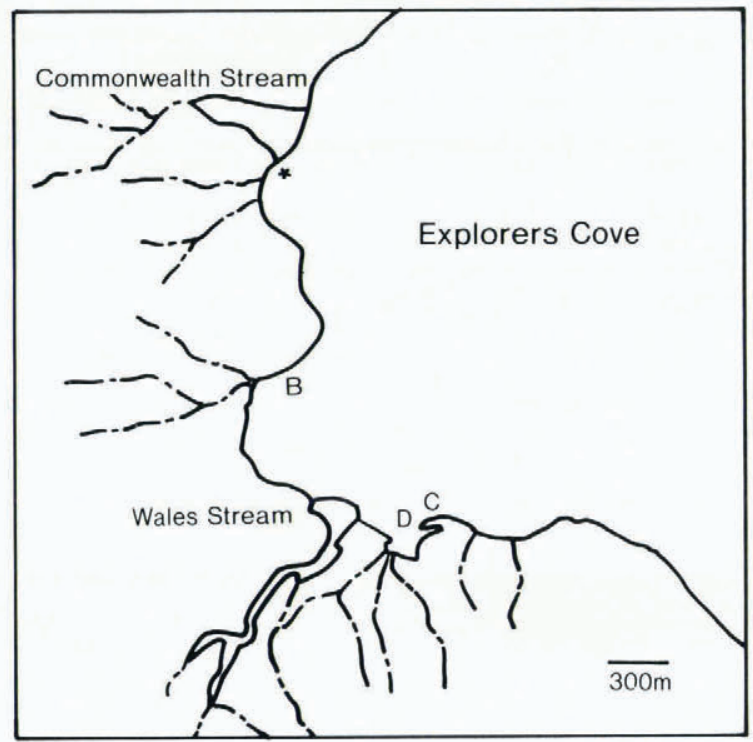

Fig. 4. The locations of the ice cliffs in Explorers Cove. The asterisk represents the ice cliff which was seen in the distance but not approached (see text).

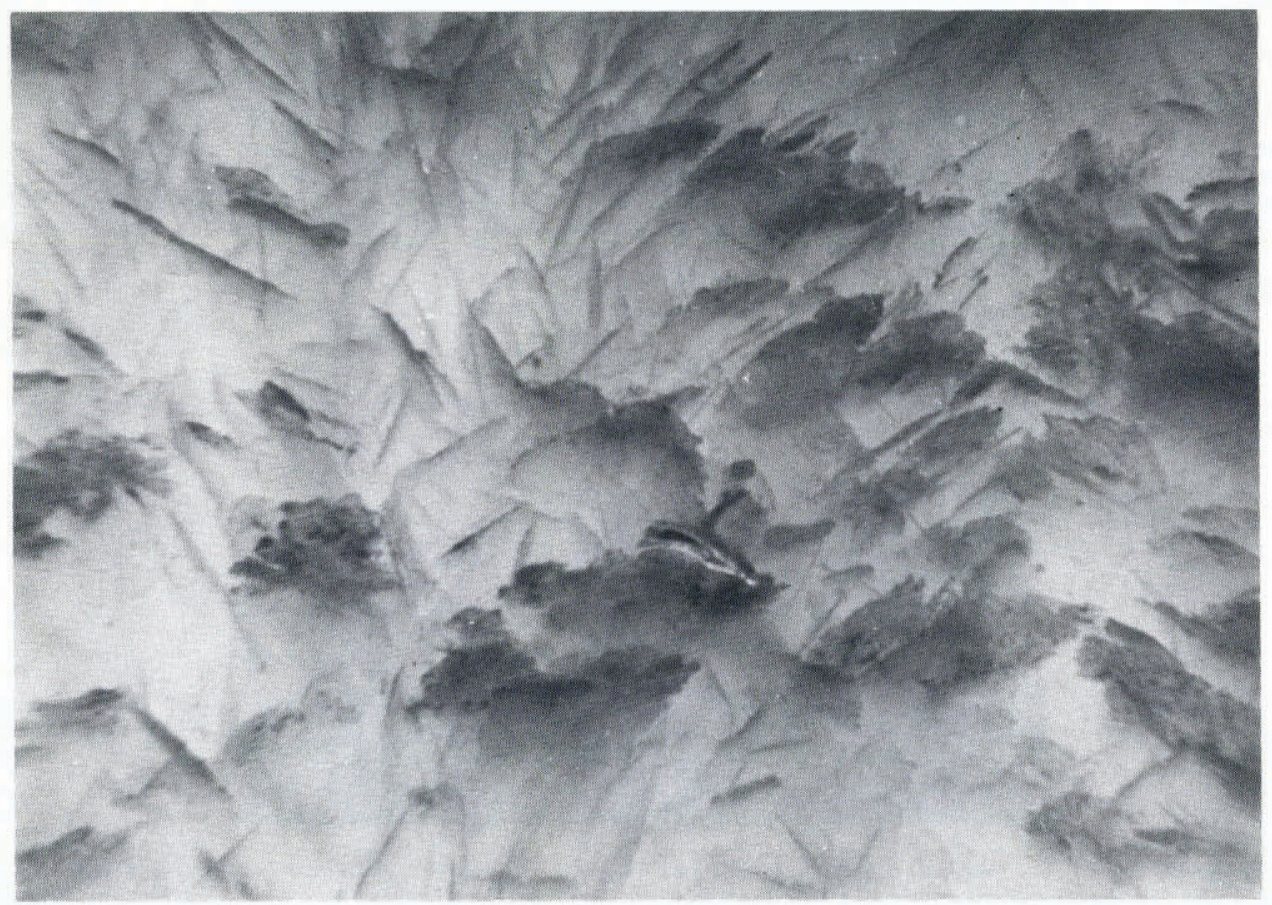

Fig. 5. Platelets of ice on the upper face of ice cliff "C". Near the center of the photograph is a live scallop. Adamussium colbecki, perched on the platelets. The largest platelets are approximately $10 \mathrm{~cm}$ across. 
increased. Beyond the "spreading" lower edge of the cliff, the mud bottom was indurated with coarse ice crystals to a distance of about $1 \mathrm{~m}$.

The second ice cliff (Figs 2C and 4) was in many respects similar to the one previously described but it was smaller, $6 \mathrm{~m}$ high with a length of approximately $70 \mathrm{~m}$ (Fig. $3 \mathrm{~b}$ and c). The flanks of this cliff rest in shallow sandy areas. The top of the cliff intersects the immediately adjacent tidal platform approximately $2 \mathrm{~m}$ from the outer edge of the cliff. As with the previous cliff, the upper $2 \mathrm{~m}$ of the cliff face was covered with ice platelets (Fig. 5) and the sediment along the base was filled with ice crystals.

The third ice cliff was very small (Figs 2D and 4), approximately $1 \mathrm{~m}$ high and covered with ice platelets. Its appearance suggested that it was similar to the larger cliffs of Explorers Cove, except that it was buried in sediment apart from the upper $1 \mathrm{~m}$. A fourth ice cliff was seen in the distance on the north side of the cove (Fig. 4); however, it was not closely investigated.

E. Herbertson Glacier. This ice cliff is located approximately $2 \mathrm{~km}$ to the west of Herbertson Glacier (Fig. 1). The adjacent shore is formed of steep cobble-covered moraine deposits. The cliff is about $20 \mathrm{~m}$ high and is almost entirely composed of opaque white ice. The cliff face was covered with an irregular array of bumps; there was no suggestion of ablation cups on its surface. The cliff was not vertical, as were the cliffs at Explorers Cove. The upper parts of this cliff overhang were approximately $10 \mathrm{~m}$ (Fig. 2E). The lower edge, as with the cliffs at Explorers Cove, extends outward in a skirt. Boulders, cobbles, and an occasional scallop, Adamussium colbecki, were imbedded in the clearer ice of the skirt. Underwater, neither end of the cliff could be seen, though it extended for at least $300 \mathrm{~m}$. At the surface, the tidal crack in the sea ice, which is at the outer edge of the ice cliff, is approximately $40 \mathrm{~m}$ from the shore. The band of shoreward ice, which is underlain by the ice cliff, extends laterally to Bowers Piedmont Glacier and towards Ferrar Glacier to the west. If this band indicates the presence and width of the ice cliff, it may be as long as $10 \mathrm{~km}$.

F. Strand Moraines. This geographic feature is so named because it is a moraine perched on the seaward edge of Bowers Piedmont Glacier. The underwater ice cliff is actually the face of the glacier. The upper approximately $15 \mathrm{~m}$ of the face was composed of opaque white ice, which, as with the ice cliff near Herbertson Glacier, was covered with bumps. This part of the face overhung the balance of the cliff by approximately $5 \mathrm{~m}$. Below this $15 \mathrm{~m}$ band of opaque ice, the ice was clear except for wavy bands of sediment. This clear ice extended beyond the diving depth limit of $32 \mathrm{~m}$. It appeared to go to a depth of at least $60 \mathrm{~m}$, the approximate limit of visibility (Fig. 2F). The lower clear ice surface was covered with ablation cups. Melting was apparent in the regions which contained sediment, as particles of sediment could be seen falling from its surface. Collections of free sediment in occasional small pockets in the face provided further evidence of melting. The lateral extent of the cliff face is assumed to be co-extensive with the edge of Bowers Piedmont Glacier.

G. Cape Chocolate. The land at this location is composed of an ice-cored moraine (Taylor, 1914; Wright and Priestley, 1922; Healy, 1975). The ice cliff at the base of Salmon Bay, inside the cape, is fundamentally different from any other of the ice cliffs observed (Fig. 2G). Rather than being described as a cliff, it would be more proper to call it a slope. The upper edge of the slope was at $2 \mathrm{~m}$ depth; however, the height of the slope at any position along its edge was variable. The slope was completely buried by sediment on the western side of the dive site, while 
to the east the lower edge of the exposed ice slope plunged off to at least $50 \mathrm{~m}$ (the water was extremely turbid, reducing visibility to about $20 \mathrm{~m}$ ). The slope was angled shoreward at approximately $15^{\circ}$ from the vertical. The entire surface was composed of opaque white ice, without any appearance of included sediment, to at least $25 \mathrm{~m}$ where exposed. The surface was dissected by streams of sediment which ran down from the shallows, shoreward of the slope edge.

H. Miers Valley. Like the Cape Chocolate area, the coast at Miers Valley is composed of an icecored moraine (Debenham, 1921; Healy, 1975). The form of the ice cliff is complex. The upper part of the cliff slopes toward shore, as at Cape Chocolate, while the lower part is overhung, as at Strand Moraines and Herbertson Glacier (Fig. 2H). The cliff was $23 \mathrm{~m}$ high. The base entered the sediment nearly vertically and without a trace of a skirt, as seen at Herbertson Glacier and Explorers Cove. The cliff was composed of opaque white ice, without any visible trace of sediment. The overhanging edge had been heavily dissected by streams of sediment which trickled down from the moraine-covered shore. The sediment at the base of the cliff, largely silt and mud, did not contain any ice crystals or evidence of freezing.

\section{Discussion}

Submarine ice cliffs are a seemingly ubiquitous feature of the shallow water of the west side of McMurdo Sound. They appear not only where they might be expected, i.e. adjacent to known ice-cored moraines, but also at Explorers Cove, at the mouth of Taylor Dry Valley, which is not known to be ice-cored. The connection between the presence of an ice cliff and the presence of an ice core, given the situation at Discovery Bluff, is not necessary. There would seem, however, to be a greater probability of a connection where ice cliffs are adjacent to extensive moraines.

The ice cliff at Discovery Bluff is fundamentally different from the other ice cliffs observed. It is not set in or under a moraine; rather it is a veneer of ice which covers solid rock. It may represent a peculiar form of ice foot. Its mode of formation and degree of persistence are unknown, but it would appear to have been frozen directly on to the surface of the rock.

Although it has long been known that the coast of the south-west side of McMurdo Sound is ice-cored (David and Priestley, 1914; Taylor, 1914, 1922; Debenham, 1921; Healy, 1975), the presence of numerous and extensive undersea ice cliffs at Explorers Cove is strong evidence that the mouth of Taylor Dry Valley possesses a number of previously unknown ice cores. The ice cores at Cape Chocolate and Miers Valley are easily discovered on land, as they are only $15-20 \mathrm{~cm}$ under the surface of the moraine (personal observation). Cursory inspection of the area around Explorers Cove did not reveal any ice cores, at least to a depth of $40 \mathrm{~cm}$. This is not sufficient evidence to argue against an ice core's presence, as Healy (1975) stated that ice cores around Lakes Chad and Fryxell in lower Taylor Dry Valley (Fig. 1) are under more than $2 \mathrm{~m}$ of moraine. This suggests that extensive excavations may be required to locate ice cores on the shore of Explorers Cove. The Dry Valley Drilling Project (see McGinnis, 1981) did not locate any ice cores in their work at Explorers Cove, but this may be due only to the fortuitous positioning of the drill sites. The simple presence of the cliffs and the obvious parallels with Cape Chocolate and Miers Valley suggest that there may be ice cores at the mouth of Taylor Dry Valley. The presence of conical pools in the intertidal zone of Explorers Cove (paper by DeLaca and Stockton in preparation) is further evidence of the melting of an ice core under a moraine. Debenham (1921) reported such kettle-like structures in the moraine flanking Koettlitz Glacier. 
Healy (1975) reported that kettles are abundant thermokarst features in the moraines around McMurdo Sound.

The presence of the large ice cliff at Herbertson Glacier and the plausible evidence that this ice cliff extends from Bowers Piedmont Glacier to the foot of Ferrar Glacier suggest that the northern flank at the eastern end of the Royal Society Range (Fig. 1) is an ice-cored moraine. Oliver and others (1978) reported an ice cliff very close to the foot of Ferrar Glacier, which is approximately $5 \mathrm{~km}$ from the site described here. This supports the suggestion of the extent of the ice cliff and, by extension, the ice core in the adjacent moraine.

The comparison of the shoreline and glacier-edge positions from pre-1970 surveys with the current coastline on the south side of New Harbour suggests that the coastline itself is not stable (Fig. 6). Although the early expedition surveys are not always accurate in detail, it can be seen that a tongue of ice extended along the southern side of New Harbour from Ferrar Glacier to Bowers Piedmont Glacier. This structure was described as the most characteristic feature of the snout of Ferrar Glacier (Taylor, 1914). Wright and Priestley (1922) figured it as a narrow band. In the maps compiled from information from 1947 through the mid-1960's, this structure appeared to be greatly enlarged (Haskell and others, 1965; Bull, 1966; Chapman-Smith, 1981). [Some maps published in the 1960's are based on those of the British Antarctic ("Terra Nova") Expedition, 1910-13, e.g. Péwé, 1961; Speden, 1962.| The current United States Geological Survey map contour for the glacier and associated coastline (Fig. 6D) demonstrates that this large mass of ice disappeared, along with a part of Ferrar Glacier. Although no direct connection can be made between the presence of the ice cliff on the south side of New Harbour, which may be enlarging, and the previous existence of a large mass of shore-attached ice on the same shore, it is perhaps useful to consider the possibility. If the ice cliff is growing, it might become unstable and break away from the shore.

The attitudes of the various cliff faces may reflect the growth or decay of an ice cliff. Of all the ice cliffs, only the one at Cape Chocolate was not vertical or overhanging. The site where this cliff was observed was at the base of Salmon Bay, inside the cape. Oliver and others (1978) observed the submerged cliff face on the outside of this cape. They described an overhanging upper cliff, which is similar to the cliff at Strand Moraines. At the base of Cape Chocolate is a small dendritic tidal bay, which nearly separates the cape from the mainland (Speden, 1960; personal observation). Such tidal bays capture, store, and release large amounts of thermal energy (paper by T. E. DeLaca and W. L. Stockton in preparation). These melt pools may have caused the melting of the upper parts of the ice cliff in the bay. A similar process may be involved in the shaping of the ice cliff at Miers Valley. At the base of Miers Valley is a small tidal bay, which might provide sufficient energy to melt the upper parts of the cliff.

An important question concerning the ice cliffs is: what is the source of the ice of which they are composed? Two distinct sources are possible: ice cores in adjacent moraines which are exposed underwater or the submarine freezing of large amounts of sea-water. Strand Moraines is a moraine perched on a glacier and the ice face below $15 \mathrm{~m}$ is certainly glacier ice. This lower surface is melting, as evidenced by ablation cups and loose sediment. However, the upper surface, shallower than $15 \mathrm{~m}$, does not show any evidence of melting. This surface is opaque white, similar in opacity to that of newly formed sea ice. The strong overhang would also appear to be suggestive of accretion. A comparatively rapid rate of freezing at the surface, with a decreasing rate with increasing depth, would produce an overhang. If the presence of an overhang and the opacity of the ice are sufficient evidence that an ice cliff is accreting, the ice cliff near Herbertson Glacier must also be growing (note Fig. 6). 

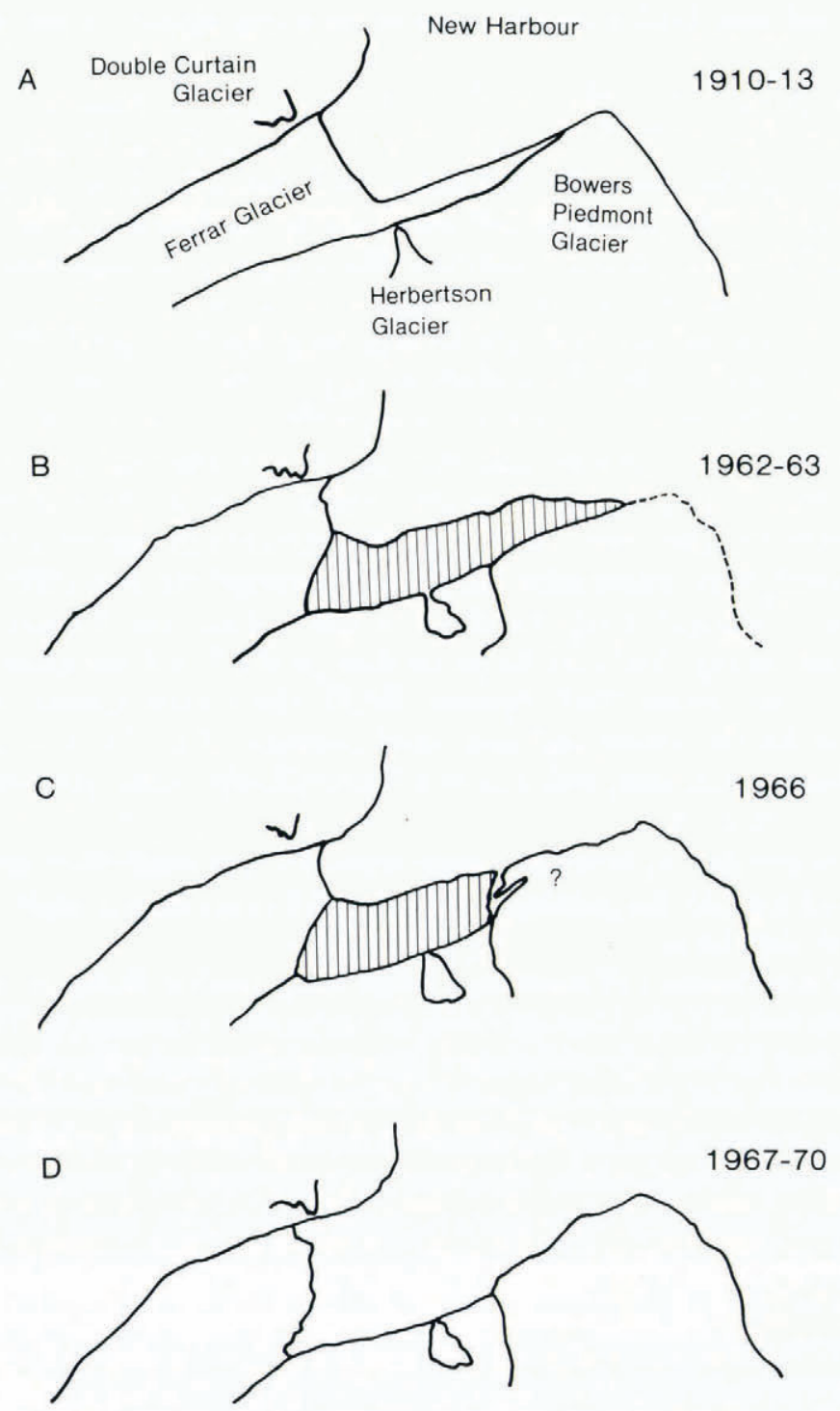

Fig. 6. The changes in the "glacial" ice associated with Ferrar Glacier. 1910-13: from Wright and Priestley (1922). 1962-63: from Haskell and others (1965). 1966: US Defense Mapping Agency Stock No. 29AC029321. 1967-70: from US Geological Survey-Ross Island, Antarctica $\left(S T 57-60 / 6^{*}\left(162^{\circ} \mathrm{E}-170^{\circ} \mathrm{E}\right)\right)$. The hatched area is of particular interest.

Evidence has already been presented which suggests that the ice cliffs at Explorers Cove are underwater exposures of ice cores. However, the presence of ice platelets on the upper parts of the cliffs is evidence of accretion, even if these fragile crystals are only seasonal. The absence of an overhang on any of the cliffs in the cove would also argue against accretion of significant amounts of ice on the cliff faces. If accretion is occurring, it would appear to be uniform over the 
face, or the face is truncated for unknown reasons. Explorers Cove possesses a number of simple and dendritic tidal pond systems (paper by DeLaca and Stockton in preparation), which are similar to those at Cape Chocolate. The effect of this heat source may influence the character of these cliffs. Preliminary isotopic analyses are under way which may distinguish the origins of the ice cliffs at Explorers Cove (personal communication from M. DeNiro).

\section{CONCLuSions}

Submarine ice cliffs have been observed adjacent to known ice-cored moraines on the west side of McMurdo Sound: Miers Valley, Cape Chocolate, and Strand Moraines. They have also been observed where no ice core has been previously reported: near Herbertson Glacier, Explorers Cove, and Discovery Bluff. The presence of the ice cliffs at Explorers Cove, along with some surface evidence, suggests the presence of ice cores in the mouth of Taylor Dry Valley. The presence of the ice cliff near Herbertson Glacier may also be evidence of an adjacent ice core.

Submarine ice cliffs are an unusual underwater feature. Their origin and fate are presently unknown. They may represent submarine expressions of permafrost or remnants of previous glaciers. Limited evidence suggests they may be a common underwater feature of the west side of McMurdo Sound.

\section{ACKNOWLEDGEMENTS}

I thank the following people who accompanied me during the ice-cliff dives: T. L. Roberts, R. B. Sharman, T. E. DeLaca, L. S. Mullineaux, G. T. Williams, R. L. Moe, D. S. Marks, and J. H. Wood. The manuscript was read and commented on by T. E. DeLaca and R. K. Cowen. This work was supported by NSF Grant DPP80-03432 to T. E. DeLaca.

MS. received 29 September 1982

\section{REFERENCES}

Bull, C. B. B. 1966. Climatological observations in ice-free areas of southern Victoria Land, Antarctica. (In Rubin, M. J., ed. Studies in Antarctic meteorology. Washington, D.C., American Geophysical Union. p. $177-94$. (Antarctic Research Series, Vol. 9.))

Chapman-Smith, M. 1981. The Taylor Formation (Holocene) and its macrofaunas, Taylor Dry Valley, Antarctica. (In McGinnis, L. D., ed. Dry Valley Drilling Project. Washington, D.C., American Geophysical Union, p. 365-78. (Antarctic Research Series, Vol. 33.))

David, T. W. E., and Priestley, R. E. 1914. Glaciology, physiography, stratigraphy, and tectonic geology of south Victoria Land, with short notes on palaeontology by T. G. Taylor and E. J. Goddard. London, William Heinemann. (Reports on the Scientific Investigations of the British Antarctic Expedition, 1907-09. Geology, Vol. 1.)

Debenham, F. 1921. Recent and local deposits of McMurdo Sound region. British Antarctic ("Terra Nova") Expedition, 1910. Natural History Report. Geology (London, British Museum (Natural History)), Vol. 1, No. 3. p. $63-100$.

Haskell, T. R., and others. 1965. The geology of the middle and lower Taylor Valley of south Victoria Land. Antarctica, by T. R. Haskell, J. P. Kennett, M. W. Prebble, G. Smith, and I. A. G. Wells. Transactions of the Royal Society of New Zealand. Geology, Vol. 2, No. 12, p. 169-86.

Healy, T. R. 1975. Thermokarst_a mechanism of de-icing ice-cored moraines. Boreas, Vol. 4, No. 1, p. $19-23$.

McGinnis, L. D., ed. 1981. Dry Valley Drilling Project. Washington, D.C., American Geophysical Union. (Antarctic Research Series, Vol. 33.) 
Oliver, J. S., and others. 1978. Observations on submerged glacial ice in McMurdo Sound, Antarctica, by J. S. Oliver, E. F. O'Connor, and D. J. Watson. Journal of Glaciology, Vol. 20, No. 82, p. 115-21.

Péwé, T. L. 1961. Multiple glaciation in the McMurdo Sound region, Antarctica-a progress report. I.G.Y. Glaciological Report Series (New York), No. 4, p. 25-49.

Speden, I. G. 1960. Post-glacial terraces near Cape Chocolate, McMurdo Sound, Antarctica. New Zealand Journal of Geology and Geophysics, Vol. 3, No. 2, p. 203-17.

Speden, I. G. 1962. Fossiliferous Quaternary marine deposits in the McMurdo Sound region, Antarctica. New Zealand Journal of Geology and Geophysics, Vol. 5, No. 5, p. 746-77.

Taylor, T. G. 1914. Physiography and glacial geology of East Antarctica. Geographical Journal, Vol. 44, No. 4, p. $365-82$; No. 5 , p. 452-67; No. 6, p. 553-71.

Taylor, T. G. 1922. The physiography of the McMurdo Sound and Granite Harbour region. London, Harrison and Sons Ltd. (British Antarctica (Terra Nova) Expedition, 1910-1913.)

Wright, C. S., and Priestley, R. E. 1922. Glaciology. London, Harrison and Sons Ltd. (British Antarctic (Terra Nova) Expedition, 1910-1913.) 